\title{
KAJIAN KINERJA PENYULUH PERTANIAN DI DESA TOROUT KECAMATAN TOMPASO BARU
}

\author{
Sitti Nurlela Mokoginta \\ Vicky R. B. Moniaga \\ Melsje Y. Memah
}

\begin{abstract}
This study aims to describe the performance of agricultural extension workers in Torout Village, Tompaso Baru Subdistrict. This research was conducted in the village of Torout District of Tompaso Baru for 3 months from May to July 2017 of preparation, data collection through the preparation of research reports. Sampling method is done purposively (purposive), on paddy farmer and corn farmer. The method used in this study using primary and secondary. The method of analysis used in this research is descriptive analysis method. The results showed that the performance of agricultural extension in the Village Torout District of Tompaso Baru with 9 indicators which 6 indicators 3 indicators categorized as high and very high. The success of agricultural extension is a requirement of farmers. Agricultural extension that can be realized if supported by the presence of competent trainers. Agricultural extension are expected to have the ability to carry out complex work, on the basis of professional ability specified, including skills to plan, implement activities, solve problems with responsibilities independently at a certain level, managerial skills and be able to follow the development, knowledge and technologies in the field of expertise.
\end{abstract}

Keywords: performance review, agricultural extension, Torout village, Tompaso Baru District.

\begin{abstract}
ABSTRAK
Penelitian ini bertujuan mendeskripsikan kinerja penyuluh pertanian di Desa Torout Kecamatan Tompaso Baru. Penelitian ini dilakukan di Desa Torout Kecamatan Tompaso Baru selama 3 bulan mulai dari bulan Mei sampai bulan Juli 2017 dari persiapan, pengambilan data sampai pada penyusunan laporan hasil penelitian. Metode pengambilan sampel dilakukan secara sengaja (purposive), pada petani padi sawah dan petani jagung. Metode yang digunakan dalam penelitian ini menggunakan primer dan sekunder. Metode analisis yang digunakan dalam penelitian ini adalah metode analisis deskriptif. Hasil penelitian menunjukan bahwa kinerja penyuluh pertanian di Desa Torout Kecamatan Tompaso Baru dengan 9 indikator dimana 6 indikator dikategorikan tinggi dan 3 indikator sangat tinggi. Keberhasilan penyuluhan pertanian merupakan kebutuhan dari petani. Penyuluhan pertanian yang dapat terwujud apabila didukung oleh keberadaan para penyuluh yang kompeten. Penyuluh pertanian diharapkan memiliki kemampuan dalam melaksanakan pekerjaan yang kompleks, dengan dasar kemampuan profesional tertentu, termasuk ketrampilan merencanakan, melaksanakan kegiatan, memecahkan masalah dengan tanggung jawab mandiri pada tingkat tertentu, memiliki ketrampilan manajerial serta mampu mengikuti perkembangan, pengetahuan, dan teknologi di dalam bidang keahliannya.
\end{abstract}

Kata kunci: kajian kinerja, penyuluh pertanian, Desa Torout, Kecamatan Tompaso Baru. 


\section{PENDAHULUAN}

\section{Latar Belakang}

Peran sektor pertanian dalam pembangunan Indonesia sangat pesat dan potensi pertanian Indonesia juga sangat besar untuk dikembangkan namun pada kenyataannya pertanian masih memiliki banyak kendala dalam pengembangannya, bukan hanya dari sudut teknologinya semata tetapi juga dari sudut manusianya, yaitu para petani itu sendiri. Sehubungan dengan itu, pengembangan dan peningkatan kompetensi petani perlu senantiasa dilakukan agar petani menjadi petani yang bukan hanya objek pembangunan tetapi sebagai subjek pembangunan. Pertanian selalu penuh dengan tantangan dan kemungkinan, karenanya para petani harus dikembangkan agar secara bertahap memiliki kemampuan intelektual yang meningkat, perbendaharaan informasi yang cukup dan mampu merencanakan serta memutuskan sesuatu yang dianggap terbaik untuk dirinya (Slamet, 2003).

Undang-undang No.16/2006 tentang Sistem Penyuluhan Pertanian, Peternakan dan Kehutanan bahwa diperlukan sumberdaya manusia termasuk petani yang berkualitas handal dan berkemampuan manajerial, kewirausahaan dan organisasi bisnis sehingga bersama-sama dengan pelaku pembangunan pertanian, peternakan dan kehutanan mampu membangun usaha dari hulu sampai dengan hilir yang berdaya saing tinggi dan berperan serta melestarikan hutan dan lingkungan hidup sejalan dengan prinsip pembangunan yang berkelanjutan. Penyuluhan pertanian di Indonesia telah mempunyai sejarah yang cukup panjang, dimulai sejak abad 20 di masa penjajahan. Penyuluhan bermula adanya kebutuhan untuk meningkatkan hasil pertanian, baik untuk kepentingan penjajah maupun untuk mencukupi kebutuhan pribumi.

Perkembangan penyuluhan di Indonesia sangat mengalami kemajuan, perkembangan itu memang sesuai dengan tuntutan masyarakat tani, dalam rangka pencapaian tujuan penyuluhan itu sendiri untuk meningkatkan pendapatan dan kesejahteraan petani. Penyuluhan tidak diartikan sebagai transfer teknologi lagi, karena kebutuhan petani tidak hanya berkutat di lahan usahatani saja, masyarakat tani pun tidak bisa lagi di anggap sebagai orang-orang yang tidak berkemampuan, mereka adalah orang-orang yang sudah berpengalaman yang perlu diakui keberadaannya (UU No 16/2006).

Penyuluhan adalah hubungan kemitraan antara pemerintah, tuan tanah dan masyarakat yang menyediakan pelayanan dan pendidikan terencana untuk menemukan kebutuhan masyarakat. Penyuluhan juga adalah sistem pendidikan luar sekolah di mana orang belajar bagaimana mengerjakan sesuatu yang berkaitan dengan pertanian. Tujuan utamanya adalah memajukan kesejahteraan mayarakat (Kelsey and Cannon, 2001).

Penyuluhan pertanian adalah proses perubahan sosial, ekonomi dan politik untuk memberdayakan dan memperkuat kemampuan masyarakat melalui proses belajar bersama yang partisipatif, kelembagaan yang terlibat dalam proses pembangunan demi terwujudnya kehidupan yang semakin berdaya, mandiri dan partisipatif yang semakin sejahtera secara berkelanjutan. Penyuluh pertanian harus dilakukan secara terus menerus oleh pemerintah atau suatu lembaga penyuluhan agar petani selalu tahu, mau dan mampu mengadopsi inovasi demi tercapainya peningkatan produktivitas dan pendapatan usaha tani guna memperbaiki mutu hidup atau kesejahteraan masyarakat secara keseluruhan. Oleh karena itu penyuluhan akan membutuhkan tenaga-tenaga penyuluh yang handal agar dapat melaksanakan kegiatan penyuluhan pertanian yang direncanakan (Mardikanto dkk, 2001).

Menurut Bernardin dan Russel (Mardikanto, 1993) mendefinisikan kinerja sebagai catatan outcome yang dihasilkan dari fungsi pegawai tertentu dan kontribusi anggota organisasi terhadap organisasinya, yang dapat diukur dengan penilaian kinerja sebagai gerakan perbuatan, pelaksanaan 
kegiatan atau tindakan sadar yang diarahkan untuk mencapai suatu tujuan atau target tertentu. Tanpa adanya kinerja berarti tidak ada upaya untuk mencapai hasil atau target dan tidak akan terjadi suatu perubahan sedikitpun dari kualitas kinerja nantinya akan berpengaruh kepada hasil. Kinerja yang baik memiliki beberapa karakteristik yaitu rasional, konsisten, tepat, efisien, terarah, disiplin dengan waktu dan berorientasi pada kerjasama kelompok. Jadi, kinerja merupakan implementasi dari rencana yang telah disusun melalui kinerja yang bersumber daya manusia dan memiliki kemampuan, kompetensi, motivasi dan kepentingan dengan menghargai dan memperlakukan sumber daya manusianya supaya mempengaruhi sikap dan perilakunya dalam menjalankan suatu kinerja.

Sektor pertanian khususnya padi sawah merupakan mata pencaharian utama bagi masyarakat di desa Torout Kecamatan Tompaso Baru. Desa Torout merupakan salah satu desa yang terdapat petani padi sawah, petani jagung dan petani cengkih. Luas lahan pertanian khususnya sawah irigasi adalah $335 \mathrm{Ha}$. Jadi lahan yang dimanfaatkan oleh petani $85 \%$ dan terdapat $15 \%$ lahan yang belum dimanfaatkan oleh petani di Desa Torout. Maka dari itu, perlu adanya penyuluhan pertanian di Desa untuk membuat para petani dapat meningkatkan usahanya dan memanfaatkan lahan pertanian yang ada. Di Desa Torout masih terdapat lahanlahan pertanian yang belum dimanfaatkan oleh petani, seperti lahan ladang yang masih dibiarkan begitu saja, padahal lahan tersebut dapat dijadikan lahan pertanian untuk tanaman jagung ataupun cengkih. Sehingga sangat dibutuhkan peran dari pihak pemerintah dalam hal ini tenaga penyuluh baik tenaga penyuluh tingkat Kecamatan ataupun penyuluh tingkat Desa, untuk merubah pola pikir masyarakat tentang pemanfaatan lahan pertanian guna mendapatkan hasil pertanian yang maksimal dan menguntungkan bagi masyarakat di Desa Torout.

Beberapa kemampuan penyuluh yang di pandang petani perlu di tingkatkan adalah pemahaman yang baik terhadap potensi sumber daya di wilayah binaan penyuluh, budaya dan kebutuhan masyarakat petani. Untuk mengetahui sampai sejauh mana keberhasilan kinerja penyuluh pertanian di tingkat lapangan, maka perlu dilakukan penelitian terhadap penyuluh pertanian. Di lapangan persepsi sebagian besar petani terhadap kemampuan penyuluh yang terkait dengan penguasaan penyuluh mengenai teknik budidaya komoditas pertanian di nilai memadai termasuk pengetahuan produksi, tanaman dan ternak. Penyuluh di nilai mampu menjelaskan inovasi suatu teknologi dan dapat berkomunikasi dengan bahasa yang mudah di pahami petani (BP3K Kecamatan Tompaso Baru, 2016).

Penulis tertarik untuk melakukan suatu penelitian dengan judul Kajian Kinerja Penyuluh Pertanian di Desa Torout Kecamatan Tompaso Baru.

\section{Perumusan Masalah}

Berdasarkan latar belakang, maka yang menjadi masalah dalam penelitian ini adalah bagaimana kinerja penyuluh pertanian di Desa Torout Kecamatan Tompaso Baru?

\section{Tujuan Penelitian}

Tujuan penelitian ini mendeskripsikan kinerja penyuluh pertanian di Desa Torout Kecamatan Tompaso Baru.

\section{Manfaat Penelitian}

Manfaat penelitian ini sebagai sumber ilmu pengetahuan tentang kinerja penyuluh pertanian. Diharapkan kepada para pembaca untuk mendapat pengetahuan tentang kinerja penyuluh pertanian pada petani padi sawah dan petani jagung. Penulisan ini juga diharapkan dapat menjadi bahan studi referensi untuk penulis-penulis selanjutnya dan referensi dalam melaksanakan penelitian selanjutnya.

\section{METODOLOGI PENELITIAN}

\section{Lokasi dan Waktu Penelitian}

Penelitian ini dilakukan di Desa Torout Kecamatan Tompaso Baru selama 3 bulan mulai dari bulan Mei sampai bulan Juli 2017 yaitu dari persiapan, pengambilan data sampai pada penyusunan laporan hasil penelitian. 


\section{Metode Pengambilan Sampel}

Metode pengambilan sampel dilakukan secara sengaja (purposive), pada petani padi sawah dan petani jagung. Responden petani, di pilih 15 (lima belas) orang petani padi sawah dan 15 (lima belas) orang petani jagung di Desa Torout, jadi jumlah responden petani yang di ambil adalah 30 responden.

\section{Metode Pengumpulan Data}

Metode yang digunakan dalam penelitian ini menggunakan primer dan sekunder. Data primer diperoleh dari wawancara secara langsung dengan menggunakan kuesioner, sedangkan data sekunder diperoleh melalui instansi-instansi yang berkaitan dengan penelitian ini yaitu di kantor BP3K Kecamatan Tompaso Baru.

\section{Konsep dan Pengukuran Variabel}

Adapun variabel yang di teliti dalam penelitian ini adalah sebagai berikut:

A. Karakteristik responden, meliputi :

1. Nama

2. Umur/usia responden (Tahun)

3. Jenis Kelamin

4. Tingkat pendidikan terakhir (SMA, SPMA, D3 dan Sarjana)

B. Penilaian Petani terhadap Kinerja Penyuluh
1. Penyuluh menyusun penyuluhan pertanian.

2. Penyuluh menyusun rencana kerja penyuluhan pertanian di wilayah kerja.

3. Penyuluh menyiapkan data peta wilayah untuk pengembangan teknologi spesifik lokasi dengan pengwilayaan komoditas unggulan.

4. Penyuluh mensosialisasikan informasi teknologi pertanian secara merata dengan kebutuhan petani.

5. Penyuluh menumbuh kembangkan keberdayaan dan kemandirian petani.

6. Penyuluh mewujudkan kemitraan usaha antara petani dengan pengusaha yang saling menguntungkan.

7. Penyuluh mewujudkan akses petani ke lembaga keuangan, informasi dan sarana produksi.
8. Penyuluh meningkatkan produktifitas agribisnis komoditas unggulan.

9. Penyuluh meningkatkan pendapatan dan kesejahteraan petani.

\section{Analisis Data}

Metode analisis yang digunakan dalam penelitian ini adalah metode analisis deskriptif, di mana metode analisis ini mendeskripsikan setiap data yang di ambil. Pengamatan yang di arahkan untuk memperoleh fakta-fakta yang di analisis menggunakan metode analisis deskriptif, data hasil wawancara dari petani di olah dan di buat tabulasi, kemudian hasilnya di interpretasikan sesuai dengan tujuan yang di capai. Untuk mengetahui kinerja penyuluh pertanian di Desa Torout di gunakan Skala Likert. Berdasarkan 9 pernyataan dengan total responden 30 orang.

Dengan cara perhitungan skor masingmasing pernyataan:

Jumlah Skor Tiap Kriterium $=$ Capaian skor $\mathrm{x}$ Jumlah Responden :

$\mathrm{S} 5=5 \times 30=150$

$\mathrm{S} 4=4 \times 30=120$

$\mathrm{S} 3=3 \times 30=90$

$\mathrm{S} 2=2 \times 30=60$

$\mathrm{S} 1=1 \times 30=30$

Jumlah skor ideal untuk setiap pernyataan $($ Skor Tertinggi) $=150$

Jumlah skor terendah $=30$

Dengan Interpretasi nilai:

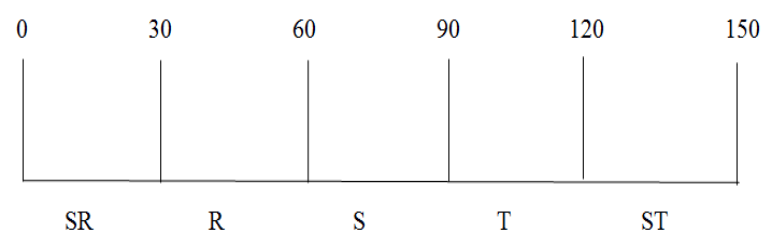

Cara perhitungan skor keseluruhan untuk mengetahui sikap :

Jumlah Skor Seluruh Kriterium = Capaian Jumlah Skor $\mathrm{x}$ Jumlah Responden $\mathrm{X}$ Instrument pernyataan

Untuk :

$\mathrm{S} 5=5 \times 30 \times 9=1350$

$\mathrm{S} 4=4 \times 30 \times 9=1080$ 
$\mathrm{S} 3=3 \times 30 \times 9=810$

$\mathrm{S} 2=2 \times 30 \times 9=540$

$\mathrm{S} 1=1 \times 30 \times 9=270$

Jumlah skor ideal untuk keseluruhan pernyataan $=1.350$ (Tertinggi)

Jumlah skor terendah $=270$ (Rendah)

Dengan interpretasi nilai:

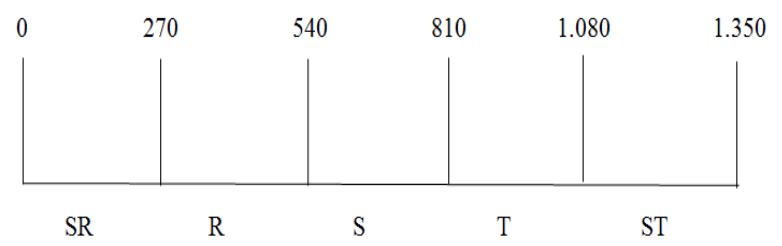

Analisis data yang digunakan merupakan analisis deskriptif yang analisis dengan menggunakan skala pengukuran Likert Scale dimana menurut Ridwan (2010) dalam buku Rumus dan Data dalam Analisis Statistika, adalah sebagai berikut :

Jumlah Skor Hasil Pengumpulan Data

Total skor $=\frac{}{\text { Jumlah Skor Ideal (Tertinggi ) }} \quad \times 100 \%$

Dengan interpretasi nilai:

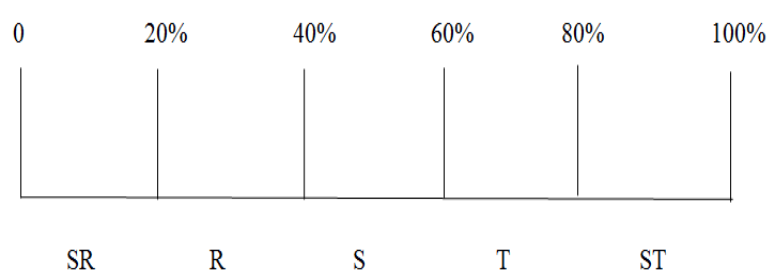

Angka 0\%-19,99\% = Sangat Tinggi

Angka 20\% - 39,99\% = Tinggi

Angka 40\% - 59,99\% = Sedang

Angka 60\% - 79,99\% = Rendah

Angka 80\% - 100\% = Sangat Rendah

\section{HASIL DAN PEMBAHASAN}

\section{Gambaran Wilayah Penelitian \\ Letak dan Luas Wilayah}

Desa Torout adalah salah satu desa yang ada di Kecamatan Tompaso Baru, dengan luas wilayah 569 ha yang terdiri dari 6 jaga. Adapun batas-batas desa yaitu,

1. Sebelah Utara berbatasan dengan Desa Lindangan
2. Sebelah Timur berbatasan dengan Desa Karowa

3. Sebelah Selatan berbatasan dengan Desa Tompaso Baru 1

4. Sebelah Barat berbatasan dengan Gunung Payung

Jumlah Kepala Keluarga Desa Torout yaitu $510 \mathrm{KK}$. Jumlah penduduk laki-laki 998 jiwa $(51,60 \%)$ dan perempuan 936 jiwa $(48,40 \%)$.

\section{Mata Pencaharian}

Masyarakat di Desa Torout Kecamatan Tompaso Baru memiliki mata pencaharian sebagai buruh tani, petani, peternak, pedagang, tukang kayu, tukang batu, penjahit, pegawai negeri, pensiunan, TNI/Polri, perangkat desa, pengrajin, industri kecil, buruh industri dan lain-lain.

Tabel 1. Mata Pencaharian Penduduk Desa Torout

\begin{tabular}{clcc}
\hline No & $\begin{array}{c}\text { Mata } \\
\text { Pencaharian }\end{array}$ & Jumlah & $\begin{array}{c}\text { Persentase } \\
(\%)\end{array}$ \\
\hline 1 & Buruh Tani & 451 & 33,43 \\
2 & Petani & 469 & 34,76 \\
3 & Peternak & 86 & 6,37 \\
4 & Pedagang & 72 & 5,33 \\
5 & Tukang Kayu & 46 & 3,40 \\
6 & Tukang Batu & 87 & 6,44 \\
7 & Penjahit & 13 & 0,96 \\
8 & PNS & 2 & 0,14 \\
9 & Pensiunan & 26 & 1,92 \\
10 & TNI/Polri & 2 & 0,14 \\
11 & Perangkat & 35 & 2,60 \\
& Desa & & \\
12 & Pengrajin & 6 & 0,44 \\
13 & Industri Kecil & 31 & 2,30 \\
14 & Buruh Industri & 7 & 0,51 \\
\hline & Jumlah & 1349 & 100 \\
\hline
\end{tabular}

Sumber: Diolah dari data primer, 2017

Total jumlah penduduk di Desa Torout Kecamatan Tompaso Baru 1934 jiwa yang memiliki mata pencaharian sebagai petani lebih banyak dari pada buruh tani, peternak, pedagang, tukang kayu, tukang batu, penjahit, PNS, pensiunan, TNI/Polri, perangkat desa, pengrajin, industri kecil dan buruh industri, hal ini dapat dilihat dari jumlah persentase yang sebesar 34, 76\%, buruh tani sebesar 33,43\%, peternak sebesar $6,37 \%$, pedagang sebesar $5,33 \%$, tukang kayu sebesar $3,40 \%$, tukang batu sebesar 
$6,44 \%$, penjahit sebesar 0,96 , PNS sebesar 0,14 , pensiunan sebesar 1,92\%, TNI/Polri sebesar 0,14, perangkat desa sebesar $2,60 \%$, pengrajin sebesar $0,44 \%$, industri kecil sebesar $2,30 \%$ dan buruh industri sebesar 0,51 dengan jumlah penduduk yang memiliki mata pencaharian sebesar 1349 jiwa. Sedangkan 585 jiwa belum memiliki pekerjaan karena terdiri dari anak-anak TK, SD, SMP, SMA dan Mahasiswa.

\section{Karakteristik Responden}

Jumlah responden dalam penelitian ini berjumlah 30 orang responden. Gambaran umum mengenai responden disajikan menurut Umur, Jenis Kelamin dan Tingkat Pendidikan.

\section{Karakteristik Responden Menurut Tingkat Umur}

Kemampuan bekerja atau melakukan aktivitas secara fisik seseorang dapat di pengaruhi oleh faktor umur. Setiap responden sudah pasti tidak sama, demikian juga dengan umur dari masing-masing responden, berikut adalah variasi umur dari tiap responden. Tabel 2 menunjukkan responden dibagi dalam 3 kelompok umur yaitu 21 - 40 tahun dengan persentase $30 \%$ (9 responden), 41-60 tahun dengan persentase $46,66 \%$ (14 responden), 61 - 80 tahun dengan persentase $23,33 \%$ (7 responden).

\section{Tabel 2. Jumlah Responden Menurut Umur}

\begin{tabular}{lccc}
\hline No & $\begin{array}{c}\text { Umur } \\
\text { (Tahun) }\end{array}$ & $\begin{array}{c}\text { Jumlah } \\
\text { Responden }\end{array}$ & $\begin{array}{c}\text { Persentase } \\
(\%)\end{array}$ \\
\hline 1 & $21-40$ & 9 & 30 \\
2 & $41-60$ & 14 & 46,66 \\
3 & $61-80$ & 7 & 23,33 \\
\hline & Jumlah & 30 & 100 \\
\hline
\end{tabular}

Sumber: Diolah dari data primer, 2017

\section{Karakteristik Responden Menurut Tingkat Pendidikan}

Semakin tinggi tingkat pendidikan seseorang, semakin banyak pula pengetahuan atau wawasan yang di miliki, baik itu menciptakan, menerapkan teknologi baru serta inovasi yang baru. Berikut hasil dari karakteristik responden berdasarkan tingkat pendidikan disajikan pada Tabel 3.
Tabel 3. Karakteristik Responden Menurut Tingkat Pendidikan

\begin{tabular}{cccc}
\hline No. & $\begin{array}{c}\text { Tingkat } \\
\text { Pendidikan }\end{array}$ & $\begin{array}{c}\text { Jumlah } \\
\text { Responden } \\
\text { (Orang) }\end{array}$ & $\begin{array}{c}\text { Persentase } \\
(\%)\end{array}$ \\
\hline 1 & SD & 10 & 33,33 \\
2 & SMP & 13 & 43,33 \\
3 & SMA & 7 & 23,33 \\
\hline & Jumlah & 30 & 100 \\
\hline
\end{tabular}

Tabel 3 menjelaskan bahwa masyarakat yang menjadi responden dalam penelitian ini memiliki tingkat pendidikan yaitu, SMA dengan persentase $23,33 \%$ (7 responden) merupakan responden paling sedikit, sedangkan SMP dengan persentase 43,33\% (13 responden) merupakan responden terbanyak, dan SD dengan persentase $33,33 \%$ (10 responden).

\section{Kajian Kinerja Penyuluh Pertanian}

Hasil tabulasi atas kajian kinerja penyuluh pertanian dapat dilihat pada tabeltabel berikut berdasarkan 9 (Sembilan) indikator keberhasilan penyuluh pertanian yang akan dipaparkan sebagai berikut.

\section{Program Penyuluhan Pertanian Dengan Kebutuhan Petani}

Tabel 4 menjelaskan tentang indikator program penyuluhan pertanian sesuai dengan kebutuhan petani. Artinya program penyuluhan pertanian akan memberikan fasilitasi pendampingan teknologi berupa materi-materi teknologi pada petani guna mendukung keberhasilan pencapaian program yang digulirkan. Program Penyuluhan Pertanian menjadi tanggungjawab Penyuluh Pertanian pada masing masing wilayah kerja di pedesaan.

Tabel 4. Program Penyuluhan Pertanian Dengan Kebutuhan Petani

\begin{tabular}{lcccc}
\hline $\begin{array}{l}\text { Alternatif } \\
\text { Jawaban }\end{array}$ & Skor & $\begin{array}{c}\text { Jumlah } \\
\text { Responden }\end{array}$ & $\begin{array}{c}\text { Persentase } \\
(\%)\end{array}$ & $\begin{array}{c}\text { Total } \\
\text { Skor }\end{array}$ \\
\hline Sangat & 5 & 16 & 53,33 & 80 \\
Tinggi & & & & \\
Tinggi & 4 & 8 & 26,67 & 32 \\
Sedang & 3 & 0 & 0 & 0 \\
Rendah & 2 & 6 & 20 & 12 \\
Sangat & 1 & 0 & 0 & 0 \\
Rendah & & & & \\
\hline Jumlah & & 30 & 100 & 124 \\
\hline
\end{tabular}


Hasil penelitian menunjukan bahwa responden yang menjawab sangat tinggi sebanyak (16 orang), artinya program yang selama ini di berikan dari penyuluh pertanian dapat langsung dilakukan oleh petani sehingga petani tidak kecewa dengan hasil panen yang mereka dapatkan. Karena pada dasarnya program-program yang di sampaikan oleh penyuluh pertanian bertujuan baik. Sedangkan yang menjawab tinggi ada ( 8 orang), artinya program yang disampaikan dapat diterapkan juga oleh petani sehingga hasil panen yang didapatkan oleh petani memuaskan. Selain yang menjawab sangat tinggi dan tinggi ada juga responden yang menjawab rendah sebanyak (6 orang) artinya, responden ini tidak mengikuti programprogram yang disampaikan oleh penyuluh, karena kekurangan informasi, keterbatasan pemikiran atau mental, sehingga mereka lebih memilih untuk menggunakan pengalaman mereka di bandingkan program-program yang disampaikan oleh penyuluh pertanian.

\section{Rencana Kerja Penyuluhan Pertanian}

Rencana kerja penyuluhan pertanian adalah suatu rencana tertulis yang dibuat oleh penyuluh pertanian untuk suatu wilayah kerja tertentu dalam bentuk kegiatan penyuluhan pertanian dan juga merupakan salah satu tugas pokok dan fungsi penyuluh pertanian yang harus dibuat seorang penyuluh dua kali dalam setahun atau paling kurang sekali setahun.

Tabel 5. Rencana Kerja Penyuluhan Pertanian

\begin{tabular}{lcccc}
\hline $\begin{array}{c}\text { Alternatif } \\
\text { Jawaban }\end{array}$ & Skor & $\begin{array}{c}\text { Jumlah } \\
\text { Responden }\end{array}$ & $\begin{array}{c}\text { Persentase } \\
(\%)\end{array}$ & $\begin{array}{c}\text { Total } \\
\text { Skor }\end{array}$ \\
\hline Sangat & 5 & 14 & 46,47 & 70 \\
Tinggi & & & & \\
Tinggi & 4 & 9 & 30 & 36 \\
Sedang & 3 & 1 & 3,33 & 3 \\
Rendah & 2 & 6 & 20 & 12 \\
Sangat & 1 & 0 & 0 & 0 \\
Rendah & & & & \\
\hline Jumlah & & 30 & 100 & 121 \\
\hline
\end{tabular}

Indikator rencana kerja penyuluh pertanian ini menunjukan bahwa responden yang menjawab sangat tinggi (14 orang) artinya bahwa dalam penyuluhan pertanian harus ada rencana kerja yang disiapkan oleh penyuluh setelah itu akan disampaikan kepada responden atau petani agar tujuan dari rencana kerja penyuluh pertanian yaitu menjadi alat kendali dalam pelaksanaan evaluasi pencapaian kinerja penyuluh pertanian yang bersangkutan, sehingga petani dengan mudah melakukan rencana kerja yang diberikan oleh penyuluh pertanian mulai dari menyiapkan, melaksanakan, mengembangkan, mengevaluasi dan melaporkan kegiatan penyuluh. Sedangkan (9 orang) menjawab tinggi artinya bahwa rencana kerja yang disampaikan dari penyuluh kepada responden atau petani itu baik sehingga dilakukan oleh petani sesuai urutan recana kerja penyuluh pertanian. Selain yang menjawab sangat tinggi dan tinggi ada juga yang menjawab sedang yaitu sebayak (1 orang), serta rendah (6 orang) di karenakan petani lebih memilih menggunakan pengalaman kerja yang telah dilakukan turuntemurun dibandingkan rencana kerja yang disampaikan oleh penyuluh pertanian kepada petani.

\section{Data Peta Wilayah Untuk Pengembangan Teknologi Spesifik Lokasi Dengan Pengwilayaan Komoditi Unggulan}

Penyusunan peta pewilayahan komoditas mempertimbangkan sifat dan karakteristik tanah sebagai prasyarat utama. Faktor-faktor tanah dan fisik lingkungan yang digunakan dalam penilaian kesesuaian lahan adalah tanah (media perakaran, retensi hara, toksisitas), iklim (suhu udara, elevasi, curah hujan) terrain (lereng, singkapan batuanbatuan dipermukaan), bahaya banjir dan bahaya erosi. Pengembangan komoditas pertanian yang sesuai secara biofisik dan menguntungkan secara ekonomi, sangat penting dalam perencanaan pengkajian teknologi untuk pengembangan komoditas unggulan dengan mempertimbangkan kemampuan sumberdaya alam, sumberdaya manusia, dan kelembagaan sehingga pengembangan komoditas tersebut berkelanjutan. 


\begin{tabular}{lcccc} 
Tabel 6. & $\begin{array}{l}\text { Data } \\
\text { Pengembangan } \\
\text { Spesifik Lokasi }\end{array}$ & $\begin{array}{r}\text { Wilayah } \\
\text { Pengwilayaan } \\
\text { Unggulan }\end{array}$ & $\begin{array}{r}\text { Untuk } \\
\text { Teknologi } \\
\text { Dengan } \\
\text { Komoditi }\end{array}$ \\
\hline $\begin{array}{l}\text { Alternatif } \\
\text { Jawaban }\end{array}$ & Skor & $\begin{array}{c}\text { Jumlah } \\
\text { Responden }\end{array}$ & $\begin{array}{c}\text { Persentase } \\
(\%)\end{array}$ & $\begin{array}{c}\text { Total } \\
\text { Skor }\end{array}$ \\
\hline Sangat & 5 & 15 & 50 & 40 \\
Tinggi & & & & \\
Tinggi & 4 & 9 & 30 & 36 \\
Sedang & 3 & 0 & 0 & 3 \\
Rendah & 2 & 6 & 20 & 12 \\
Sangat & 1 & 0 & 0 & 0 \\
Rendah & & & & \\
\hline Jumlah & \multicolumn{5}{c}{30} & 100 & 91 \\
\hline
\end{tabular}

Indikator data peta wilayah untuk pengembagan teknologi spesifikasi lokasi dengan pengwilayaan komoditi unggulan menunjukan bahwa (15 orang) menjawab sangat tinggi dan (9 orang) menjawab tinggi itu artinya bahwa untuk mengatasi tantangan pasar di masa yang akan datang perlu adanya mekanisasi dan teknologi dalam meningkatkan produksi, produktifitas dan kualitas dari hasil pertanian, sehingga petani merasa penting dengan adanya program yang diberikan oleh penyuluh pertanian. Selain itu ada (6 orang) menjawab rendah hal ini di karenakan petani atau responden mereka merasa tidak mampu dalam mengoperasikan teknologi yang diberikan oleh penyuluh.

\section{Mensosialisasikan Informasi Teknologi Pertanian Secara Merata Dengan Kebutuhan Petani}

Teknologi merupakan suatu cara ataupun sarana yang diciptakan manusia untuk memenuhi kepuasannya. Dalam penerapan teknologi pertanian misalnya, petani akan merasa puas dan bangga jika tanamannya berhasil dipanen sesuai harapan. Dalam dunia pertanian, sudah cukup banyak teknologi yang bisa diterapkan untuk mengatasi berbagai masalah dibidang pertanian. Baik itu teknologi yang dihasilkan oleh berbagai lembaga penelitian, maupun teknologi turun-temurun yang sudah menjadi kearifan lokal.
Tabel 7. Mensosialisasikan Informasi Teknologi Pertanian Secara Merata Dengan Kebutuhan Petani

\begin{tabular}{lcccc}
\hline $\begin{array}{l}\text { Alternatif } \\
\text { Jawaban }\end{array}$ & Skor & $\begin{array}{c}\text { Jumlah } \\
\text { Responden }\end{array}$ & $\begin{array}{c}\text { Persentase } \\
(\%)\end{array}$ & $\begin{array}{c}\text { Total } \\
\text { Skor }\end{array}$ \\
\hline Sangat & 5 & 14 & 46,67 & 70 \\
Tinggi & & & & \\
Tinggi & 4 & 9 & 30 & 36 \\
Sedang & 3 & 0 & 0 & 0 \\
Rendah & 2 & 7 & 23,33 & 14 \\
Sangat & 1 & 0 & 0 & 0 \\
Rendah & & & & \\
\hline Jumlah & & 30 & 100 & 120 \\
\hline
\end{tabular}

Indikator mensosialisasikan informasi teknologi pertanian secara merata dengan kebutuhan petani menunjukkan bahwa (14 orang) menjawab sangat tinggi itu artinya dengan adanya teknologi pertanian yang dapat di sosialisasikan secara merata dan sesuai dengan kebutuhan petani maka nantinya hasil panen yang didapatkan dari petani sesuai dengan apa yang di harapkan. Sedangkan (9 orang) menjawab tinggi memiliki arti yang sama dengan menjawab sangat tinggi karena teknologi yang di sosialisasikan memiliki manfaat dengan kebutuhan petani. Selain yang menjawab sangat tinggi ada juga yang menjawab rendah sebanyak (7 orang) ini dikarena mereka masih meragukan akan manfaat teknologi tersebut. Mereka khawatir akan gagal panen jika menerapkan sebuah cara yang baru.

\section{Keberdayaan dan Kemandirian Petani dan Kelompok Tani}

Pembangunan pertanian tidak terlepas dari peran serta masyarakat tani sebagai pemutar roda perekonomian negara. Dengan peran tersebut maka perlu pemberdayaan masyarakat tani sehingga petani mempunyai kekuatan yang mampu menyelesaikan masalah yang dihadapinya. Salah satu usaha pemerintah bersama petani dalam rangka membangun upaya kemandirian petani dibentuklah kelompok-kelompok tani di pedesaan. 
Tabel 8. Keberdayaan dan Kemandirian Petani dan Kelompok Tani

\begin{tabular}{lcccc}
\hline $\begin{array}{l}\text { Alternatif } \\
\text { Jawaban }\end{array}$ & Skor & $\begin{array}{c}\text { Jumlah } \\
\text { Responden }\end{array}$ & $\begin{array}{c}\text { Persentase } \\
(\%)\end{array}$ & $\begin{array}{c}\text { Total } \\
\text { Skor }\end{array}$ \\
\hline Sangat & 5 & 13 & 43,33 & 65 \\
Tinggi & & & & \\
Tinggi & 4 & 8 & 26,67 & 32 \\
Sedang & 3 & 2 & 6,67 & 6 \\
Rendah & 2 & 6 & 20 & 12 \\
Sangat & 1 & 1 & 3,33 & 1 \\
Rendah & & & & \\
\hline Jumlah & & 30 & 100 & 116 \\
\hline
\end{tabular}

Penelitian ini menunjukan bahwa responden yang menjawab sangat tinggi sebanyak (13 orang), yang menjawab tinggi ( 8 orang) itu artinya program keberdayaan dan kemandirian petani dan kelompok tani sangat baik untuk petani dan kelompok tani itu sendiri, karena dengan adanya keberdayaan dan kemandirian petani dan kelompok tani mereka akan lebih mandiri.

\section{Kemitraan Usaha antara Petani dan Pengusaha yang Saling Menguntungkan}

Pentingnya aspek kemitraan usaha antara petani dan pengusaha yang saling menguntungkan hal ini di karenakan dalam pemasaran produk tertentu diperlukan dukungan kelembagaan yang kuat. Hasil-hasil yang telah dicapai dalam pembangunan pertanian termasuk pengembangan kemitraan tidak terlepas dari peranan aktif para pelaku ekonomi seperti petani, kelompok tani, swasta, BUMN dan pemerintah. Pengembangan sistem kelembagaan yang memadukan kebijaksanaan pemerintah dengan kepentingan petani dan swasta merupakan aspek yang sangat penting sehingga tercapai kemitraan usaha yang baik.

\begin{tabular}{lcccc} 
Tabel 9. Kemitraan Usaha antara & $\begin{array}{c}\text { Petani dan } \\
\text { Pengusaha } \\
\text { Menguntungkan }\end{array}$ & $\begin{array}{c}\text { yang } \\
\text { Saling }\end{array}$ \\
\hline $\begin{array}{l}\text { Alternatif } \\
\text { Jawaban }\end{array}$ & Skor & $\begin{array}{c}\text { Jumlah } \\
\text { Responden }\end{array}$ & $\begin{array}{c}\text { Persentase } \\
(\%)\end{array}$ & $\begin{array}{c}\text { Total } \\
\text { Skor }\end{array}$ \\
\hline $\begin{array}{l}\text { Sangat } \\
\text { Tinggi }\end{array}$ & 5 & 13 & 43,33 & 65 \\
Tinggi & 4 & 9 & 30 & 36 \\
Sedang & 3 & 1 & 3,33 & 3 \\
Rendah & 2 & 5 & 16,67 & 10 \\
Sangat & 1 & 2 & 6,67 & 2 \\
Rendah & & & & \\
\hline Jumlah & & 30 & 100 & 116 \\
\hline
\end{tabular}

Kemitraan usaha antara petani dan pengusaha yang saling menguntungkan sangat baik, hal ini dapat dilihat bahwa jumlah responden yang menjawab sangat tinggi sebanyak (13 orang) dan yang menjawab tinggi ada ( 9 orang) lebih banyak dari responden yang menjawab sedang sebanyak (1 orang), rendah (5 orang) dan sangat rendah sebanyak (2 orang) itu artinya indikator adanya kemitraan usaha antara petani dan pengusaha yang saling menguntungkan selama ini sangat baik dan tentunya mendaptkan hasil yang memuaskan petani.

\section{Mewujudkan Akses Petani ke Lembaga Keuangan, Informasi, Sarana Produksi Pertanian dan Pemasaran}

Indikator mewujudkan akses petani ke lembaga keuangan, informasi, sarana produksi pertanian dan pemasaran, maka untuk mewujudkan akses petani ke lembaga keuangan dan informasi maka dibutuhkan sarana produksi pertanian (saprotan) yang baik merupakan salah satu faktor yang sangat penting dalam mendukung perkembangan atau kemajuan pertanian terutama untuk mencapai tujuan terciptanya ketahanan pangan. Pupuk dan pestisida (obat-obatan pertanian) adalah sarana produksi pertanian utama yang paling banyak diperlukan petani dalam kegiatan pertanian. Pupuk dalam hal ini terdiri dari pupuk organik (kompos, kotoran hewan, kasting, dan pupuk hijau) dan pupuk anorganik (urea, ZA, TSP, SP36 dan KCL). Sedangkan pestisida meliputi, herbisida, insektisida, fungisida, dan lainnya. Dengan semakin berkembangnya dan semakin majunya sistem pertanian di Indonesia, kombinasi yang tepat dari penggunaan sarana produksi pertanian, khususnya pupuk dan pestisida merupakan hal yang sangat penting untuk diperhatikan, sehingga permintaan sarana produksi pertanian (saprotan) yang terus meningkat.

Tabel 10. Mewujudkan Akses Petani ke Lembaga Keuangan, Informasi, Sarana Produksi Pertanian dan Pemasaran

\begin{tabular}{lcccc}
\hline $\begin{array}{l}\text { Alternatif } \\
\text { Jawaban }\end{array}$ & Skor & $\begin{array}{c}\text { Jumlah } \\
\text { Responden }\end{array}$ & $\begin{array}{c}\text { Persentase } \\
(\%)\end{array}$ & $\begin{array}{c}\text { Total } \\
\text { Skor }\end{array}$ \\
\hline Sangat & 5 & 11 & 36,37 & 55 \\
Tinggi & & & & \\
Tinggi & 4 & 10 & 33,33 & 40 \\
Sedang & 3 & 3 & 10 & 9 \\
Rendah & 2 & 6 & 20 & 12 \\
Sangat & 1 & 0 & 0 & 0 \\
Rendah & & & & \\
\hline Jumlah & & 30 & 100 & 116 \\
\hline
\end{tabular}


Hasil penelitian menunjukan bahwa (11 orang) responden menjawab sangat tinggi dan juga (10 orang) menjawab tinggi itu artinya bahwa indikator dari kinerja penyuluh pertanian dalam hal mewujudkan akses petani ke lembaga keuangan, informasi, sarana produksi pertanian dan pemasaran memiliki dampak yang baik sehingga hasil pertanian yang didapatkan dengan bantuan sarana produksi pertanian dan pemasaran dapat meningkatkan pendapatan dari petani. Selain responden yang menjawab sangat sesuai dan sesuai ada juga yang menjawab sedang sebanyak (3 orang), rendah (6 orang), hal ini dikarenakan masih ada petani yang ragu-ragu dan juga merasa tidak sesuai dengan pengalaman yang sering mereka gunakan karena bagi mereka ini bertolak belakang dengan yang selama ini mereka lakukan menggunakan pengalam pribadi.

\section{Meningkatkan Produktivitas Agribisnis Komuditas Unggulan}

Setiap daerah mempunyai karakteristik wilayah, penduduk, dan sumber daya yang berbeda-beda. Hal ini membuat potensi masing-masing daerah akan menjadi berbeda dalam menentukan arah kebijakan pengembangan kegiatan ekonomi di wilayahnya. Pertimbangan utama dalam meningkatkan prduktivitas agribisnis komoditas unggulan di suatu wilayah adalah komoditas yang diusahakan harus efisien dari sisi teknologi dan sosial ekonomi serta memiliki keunggulan komparatif dan kompetitif.

Tabel 11. Meningkatkan Produktivitas Agribisnis Komuditas Unggulan

\begin{tabular}{lcccc}
\hline $\begin{array}{l}\text { Alternatif } \\
\text { Jawaban }\end{array}$ & Skor & $\begin{array}{c}\text { Jumlah } \\
\text { Responden }\end{array}$ & $\begin{array}{c}\text { Persentase } \\
(\%)\end{array}$ & $\begin{array}{c}\text { Total } \\
\text { Skor }\end{array}$ \\
\hline Sangat & 5 & 11 & 36,67 & 55 \\
Tinggi & & & & \\
Tinggi & 4 & 7 & 23,33 & 28 \\
Sedang & 3 & 2 & 6,67 & 6 \\
Rendah & 2 & 10 & 33,33 & 20 \\
Sangat & 1 & 0 & 0 & 0 \\
Rendah & & & & \\
\hline Jumlah & & 30 & 100 & 109 \\
\hline
\end{tabular}

Indikator meningkatkan produktivitas agribisnis komuditas unggulan menunjukan bahwa (11 orang) responden menjawab sangat tinggi itu artinya kinerja penyuluh dalam hal peningkatan produktivitas agribisnis komuditas unggulan sangat baik karena petani merasa bahwa ada peningkatan produktivitas agribisnis pada komuditas unggulan, seperti padi sawah dan jagung, selain itu ada juga responden yang menjawab rendah sebanyak (10 orang), artinya mereka merasa bahwa indikator meningkatnya produktivitas agribisnis komoditas unggulan dari kinerja penyuluh pertanian tidak sesuai dengan kenyataan yang ada. Dan juga ada responden yang menjawab tinggi (7 orang), pastinya tidak berbeda dengan yang menjawab sangat tinggi karena memiliki arti yang sama, sedangkan yang menjawab sedang (2 orang).

\section{Meningkatkan Pendapatan dan Kesejahteraan Petani}

Mensejahterakan petani bukan hanya tentang meningkatkan pendapatan sekelompok masyarakat. Namun petani adalah salah satu elemen penting dalam mata rantai kedaulatan pangan. Jika pemerintah mampu menciptakan sebuah kebijakan yang mendorong perbaikan kehidupan petani, maka produktivitas pertanian akan meningkat. Dengan demikian, kapasitas produksi akan mampu mengimbangi laju kebutuhan pangan penduduk. Indikator meningkatkan pendapatan dan kesejahteraan petani tentunya merupakan kinerja dari penyuluh pertanian dalam menyampaikan program-program penyuluhan kepada petani, sehingga dapat meningkatakan pendapatan dan kesejahteraan petani.

Tabel 12. Meningkatkan Pendapatan dan Kesejahteraan Petani

\begin{tabular}{lcccc}
\hline $\begin{array}{l}\text { Alternatif } \\
\text { Jawaban }\end{array}$ & Skor & $\begin{array}{c}\text { Jumlah } \\
\text { Responden }\end{array}$ & $\begin{array}{c}\text { Persentase } \\
(\%)\end{array}$ & $\begin{array}{c}\text { Total } \\
\text { Skor }\end{array}$ \\
\hline Sangat & 5 & 13 & 43,33 & 65 \\
Tinggi & & & & \\
Tinggi & 4 & 9 & 30 & 36 \\
Sedang & 3 & 1 & 3,33 & 3 \\
Rendah & 2 & 5 & 16,67 & 10 \\
Sangat & 1 & 2 & 6,67 & 2 \\
Rendah & & & & \\
\hline Jumlah & & 30 & 100 & 116 \\
\hline
\end{tabular}


Hasil penelitian menunjukan bahwa jumlah responden yang menjawab sangat tinggi sebanyak (13 orang) dan tinggi sebanyak (9 orang), maka dapat diartikan bahwa petani merasa dengan adanya programprogram dari penyuluh pertanian yang dapat meningkatkan pendapatan dan kesejahteraan petani, sedangkan ada responden yang menjawab rendah sebanyak (5 orang), artinya masih ada petani yang merasa bahwa program-program dari penyuluh pertanian tidak dapat meningkatkan pendapatan dan kesehteraan petani, selain itu yang menjawab sangat rendah sebanyak (2 orang) dan sedang sebanyak (1 orang).

\section{Rekapitulasi Indeks Kinerja Penyuluh Pertanian Masing-Masing Indikator dan Interpretasi Hasil}

Penelitian ini untuk mengukur kinerja penyuluh pertanian di Desa Torout Kecamatan Tompaso Baru dengan mengambil 9 indikator sebagai tolak ukur dalam penelitian ini, yaitu:

a. Program penyuluhan pertanian dengan kebutuhan petani,

b. Rencana kerja penyuluhan pertanian,

c. Data peta wilayah untuk pengembangan teknologi spesifik lokasi dengan pengwilayaan komoditi unggulan,

d. Mensosialisasikan informasi teknologi pertanian secara merata dengan kebutuhan petani,

e. Keberdayaan dan kemandirian petani dan kelompok tani,

f. Kemitraan usaha antara petani dan pengusaha yang saling menguntungkan,

g. Mewujudkan akses petani ke lembaga keuangan, informasi, sarana produksi pertanian dan pemasaran,

h. Meningkatkan produktivitas agribisnis komuditas unggulan

i. Meningkatkan pendapatan dan kesejahteraan petani

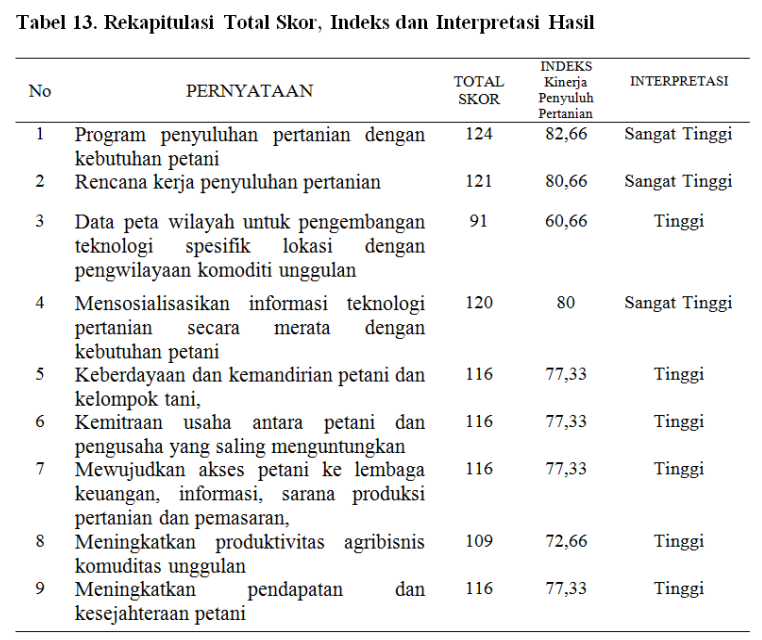

Hasil rekapitulasi menunjukan bahwa dari 9 indikator 1 sampai dengan 9 mendapatkan skor pada indeks yang tinggi $(60,66-100 \%)$. Hal ini menunjukan bahwa kinerja penyuluh pertanian di desa Torout Kecamatan Tompaso Baru tinggi. Artinya bahwa kinerja penyuluh di desa Torout baik dengan setiap indikator yang ada dan juga setiap program-program yang sudah dijalankan membuat petani semakin baik berkembang dan pendapatan petani juga meningkat.

Hasil untuk mengetahui letak kinerja penyuluh pertanian di desa Torout, maka perlu dihitung jumlah keseluruhan skor pada setiap kriterium, dimana sesuai hasil penelitian ini skor mencapai 1029 pada penelitian ini, jumlah skor ideal (skor tertinggi), yaitu 1350 (tinggi) dan jumlah skor terendah yaitu 270 (rendah). Berdasarkan data yang dihimpun dari sebanyak 9 indikator yang diajukan kepada 30 orang responden, maka diperoleh total skor 1029, secara persentase, angka indeks kinerja penyuluh pertanian terletak pada.

Kinerja Penyuluh Pertanian $=\frac{\text { Jumlah skor hasil pengumpulan data }}{\text { Jumlah skor ideal (tertinggi) }} 100 \%$

$$
=\frac{1029}{1350} \times 100 \%=76,22 \%
$$


Berdasarkan hasil analisis menggunakan skala likert, maka dapat diketahui bahwa angka indeks kinerja penyuluh pertanian di desa Torout berada pada titik $76,22 \%$ yaitu tinggi, artinya kinerja penyuluh pertanian di desa Torout Kecamatan Tompaso Baru di tinjau dari segi indikator dan juga program-program yang diberikan oleh penyuluh bahkan telah dilaksanakan oleh petani sehingga hasil dari penyuluhan yang disampaikan kepada petani dapat meningkatkan pendapatan petani.

\section{Dengan Interpretasi Nilai :}

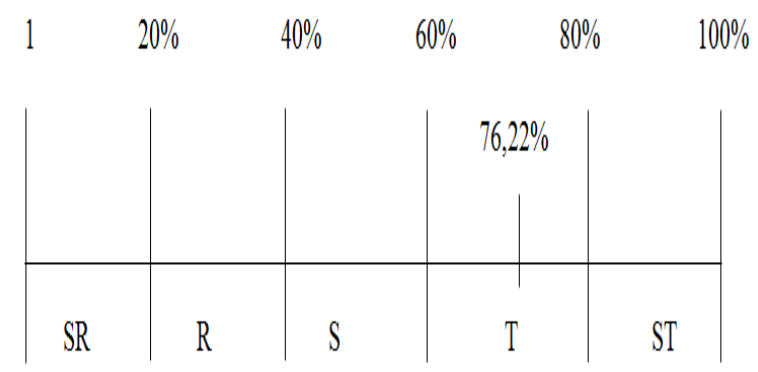

\section{KESIMPULAN DAN SARAN}

\section{Kesimpulan}

Berdasarkan hasil penelitian secara keseluruhan kinerja penyuluh pertanian di Desa Torout adalah sangat baik, dapat dilihat dari 9 kategori diantaranya 3 indikator sangat tinggi yaitu Program penyuluhan pertanian dengan kebutuhan petani, Rencana kerja penyuluhan pertanian, Mensosialisasikan informasi teknologi pertanian secara merata dengan kebutuhan petani. Dan 6 indikator dikategorikan tinggi yaitu Keberdayaan dan kemandirian petani dan kelompok tani, Kemitraan usaha antara petani dan pengusaha yang saling menguntungkan, Mewujudkan akses petani ke lembaga keuangan, informasi, sarana produksi pertanian dan pemasaran, Meningkatkan pendapatan dan kesejahteraan petani, Meningkatkan produktivitas agribisnis komoditas unggulan, Data peta wilayah untuk pengembangan teknologi spesifik lokasi dengan pengwilayaan komoditi unggulan.

\section{Saran}

Saran dari penelitian ini adalah :

1. Bagi penyuluh tetap meningkatkan kinerja penyuluhan pertanian, agar petani dapat menerima setiap program-program yang diberikan sehingga hasil pertanian mereka produktivitasnya meningkat.

2. Bagi kalangan akademis diharapkan penelitian ini dapat dijadikan referensi untuk penelitian-penelitian yang terkait dengan kajian kinerja penyuluh pertanian.

\section{DAFTAR PUSTAKA}

BP3K, Kecamatan Tompaso Baru. 2016.

Kelsey, L D and Cannon CH., 2001. Cooperative Extension Work. Comstock Publishing Associates. New York.

Mardikanto, T. 1993. Penyuluhan Pembangunan Pertanian. Surakarta: Sebelas Maret University Press.

Ridwan. 2010. Rumus dan Data dalam Analisis Statistika. Jakarta : Alfabeta.

Slamet, M. 2003. Membentuk Pola Perilaku Manusia Pembangunan. IPB Press, Bogor.

Undang Undang Republik Indonesia Nomor 16 Tahun 2006 Tentang Sistem Penyuluhan Pertanian Perikanan dan Kehutanan.Pdf (24 Mei 2015). 